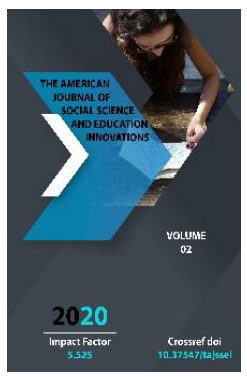

\title{
Error Classification And Methods Of Their Correction
}

\author{
Vasila Babaeva \\ Senior lecturer of Bukhara State University, Uzbekistan
}

Journal Website: http://usajournalshub.c om/index,php/tajssei

Copyright: Original content from this work may be used under the terms of the creative commons attributes 4.0 licence.

\section{ABSTRACT}

This article examines the role of error correction in teaching a foreign language at universities and their feasibility. The classification of errors and the ways of their correction are analyzed as well.

\section{KEYWORDS}

Error correction, error classification, types of error correction

\section{INTRODUCTION}

The educational reforms and regulatory documents of recent years in our republic have been developed and successfully implemented, aimed at changing the general methodology of the process of foreign language education. These documents include the New State Educational Standard of the Continuing Education System of the Republic of Uzbekistan "Requirements for the level of preparedness of graduates of all levels of education in foreign languages" (05/08/2013), developed on the basis of the Common
European Framework of Reference for Knowledge of Foreign Languages and providing a radically new approach to the system of teaching foreign languages. The purpose of teaching a foreign language at all levels of education of the Republic of Uzbekistan according to the State Educational Institution of Education is the formation of a foreign language communicative competence of students for functioning in a multicultural world in everyday, scientific and professional spheres [1]. 


\section{MATERIALS AND METHODS}

New state educational standards of higher professional education determine the requirements for the results of mastering basic educational programs, which are formulated in competencies. Many researchers in the field of teaching a foreign language are confident that it is a foreign language that is a key tool for the implementation of intercultural communication.

Learning a language is a lengthy process during which the student inevitably makes many mistakes. It is no secret that even native speakers make mistakes in speech, and those who study a foreign language, regardless of their desire, make mistakes both in oral and written speech. From the point of view of the methodology of teaching a foreign language, mistakes are different, and it is also necessary to correct them in different ways. Many teachers believe that students whose speech is constantly being corrected become more constrained and may avoid speaking, forming a language barrier. This leads to the opposite result from the original goal of communication learning.

Considering the methodology of teaching a foreign language, it seems important to determine the role and technology of error correction. The problem of correcting mistakes has always worried teachers of a foreign language. The question whether to correct mistakes or not, and if to correct, then how, largely depends on the methodology that the teacher uses in his work, as well as on the type of speech activity during which errors are corrected. The communicative method, which emerged in the $1980 \mathrm{~s}$ and is still relevant today, does not assign the main role to error correction, giving primary importance to fluency of speech and the competent use of linguistic forms. In modern methodological research, the point of view is widespread that error correction can be a positive factor in teaching adolescents and adults. [2]

Having considered a brief history of the approach to the problem of correcting errors, each teacher of a foreign language must first of all answer the following questions: 1) correct errors or not? 2) when should it be corrected and how? In teaching practice, we often had to deal with cases when students experience anxiety and fear of foreign speech, fear of mistakes, especially in oral speech, when they do not have the opportunity to use reference materials (dictionaries, synopses). In this situation, the teacher's constant and persistent correction of mistakes will not only slow down the process of expressing, but can also develop an underestimation of his abilities in the student, reduce his motivation to learn a foreign language.

\section{RESULTS AND DISCUSSIONS}

It is believed that mistakes are an integral part of the learning process, and correcting them is part of the learning process. When a teacher says, "This exercise is full of mistakes," or "They write well, but spoken language is full of mistakes," we can easily understand what he means. But if we look at this problem, then we come to the conclusion that the general meaning of the word "error" is much broader and reflects various phenomena in the use of language. Many of the professional terms that have appeared along with new textbooks have a different content, different from those adopted in traditional practice Teaching errors can be classified into:

$>$ By reasons of their occurrence: what is the reason for the error? Did it happen by chance or does the speaker think his words are correct?

$>$ By linguistic type:

$>$ Lexical error-vocabulary; 
$>$ Phonetic (incorrect pronunciation) and phonological error (substitution for the sound of the native language);

$>$ Syntax error (incorrect construction of phrases, simple and complex sentences);

$>$ Interpretation error misunderstanding the meaning of words;

$>$ Morphological (associated with nonnormative education of word forms and the use of parts of speech);

$>$ Pragmatic mistake - inability to apply the rules of conversation

$>$ Errors can also be classified as productive (in the speech and writing of the speaker) or receptive (misunderstanding of the meaning) (classification of the Linguist Tseitlin S.N.).

$>$ Foreign methodologists differentiate two types of errors:

$>$ Accidental, due to carelessness or fatigue

Admitted due to lack of knowledge

In the second case, errors occur for two reasons. The first is the influence of the native language, when the student projects grammatical and lexical structures, as well as the pronunciation of the native language into the foreign language being studied. The second reason is that the student has not yet mastered the new rules enough, and such errors will disappear as he learns. This phenomenon can be compared with the speech of young children, who, as they grow up, make fewer speech mistakes.

Attitudes towards error correction both among teachers and also among students may differ. Correction is the individual opinion of a particular teacher in relation to the statement or written work of the student. This means that the opinions of different teachers may differ in some situations - what, when and how to correct. It all depends on the purpose of the assignment, level, age and individual characteristics of the student.

It is impossible, while mastering a foreign language, to avoid mistakes completely, but it is indisputably necessary to strive to minimize them. A person who speaks a second, not his native language, regardless of his desire, will make mistakes in speech, and the first task of the teacher is to form students' positive attitude towards mistakes, explaining to them that they are an integral part of the learning process. He must clearly determine what are the causes of errors and develop techniques for correcting errors, and most importantly, learn to predict and prevent them.

\section{CONCLUSION}

Having studied this problem, we can formulate the following conclusions: Errors are an integral element of the cognition process, an indicator of the assimilation of program material by students. Refusing to correct mistakes hinders progress in learning a foreign language. The mistakes of the trainees are material for understanding and planning corrective work. When planning corrective work, the teacher must take into account the causes of errors, their categories, as well as the goals and objectives of educational activities. The teacher's intervention in correcting mistakes should be reasonable, tactful and sufficient, contribute to the formation of positive motivation and increase the self-esteem of students.

\section{REFERENCES}

1. Arkharova M.G. Correction of mistakes in the process of teaching a foreign language: theory and practice // Education. Foreign languages. Online edition for teachers. Winter 2014-2015. 
2. Balyasnikova N.S. The nature and typology of mistakes in the study of English as a second foreign language in the first Spanish. // Izvestia of the Russian State Pedagogical University. A.I. Herzen. - 2007. - No. 24.

3. Merkulova S.G. Modern approaches and correction of errors in oral speech in the study of a foreign language. // English language. Supplement to the newspaper "First September". - No. 45. -2002.

4. T. Bogdanova The role of error correction in teaching a foreign language in a nonlinguistic university. Pedagogue tribune. Scientific bulletin YIM №4. 2014. P.66-69. 